Kapata Arkeologi, 12(2), 199-212

ISSN (cetak): 1858-4101

ISSN (elektronik): 2503-0876

http://kapata-arkeologi.kemdikbud.go.id

\title{
BUDAYA MAKAN DI LUAR RUMAH DI PERKOTAAN JAWA PADA PERIODE AKHIR KOLONIAL ${ }^{1}$ \\ Eating Out Culture in Urban Java on The Late Colonial Period
}

\author{
Gregorius Andika Ariwibowo \\ Balai Pelestarian Nilai Budaya (BPNB) Jawa Barat - Indonesia \\ Jl. Cinambo No.136, Bandung, Jawa Barat \\ andikaariwibowo@gmail.com
}

Naskah diterima: 19/09/2016; direvisi: 14/11 - 18/11/2016; disetujui: 23/11/2016

Publikasi ejurnal: 30/12/2016

\begin{abstract}
Eating out behavior is one of picturesque studies which reviewing about people behavior and life style. This article developed from author thesis which described about culinary culture in Javanese Cities during late colonial era. This development is done by inserting Alan Warde and Lydia Martens concept that's research about eating out culture in England. They resumed that eating out behavior related with pleasure and amusement. According with that concept this research will describe about how eating out behavior provide an influence to life style behavior on Javanese urbans people, especially for elite and middle class society. This study used Historical studies method that focus on research of mass media, advertisement publicity, and traveloque from that's period. This study inference that eating out culture and behavior not just related with need complianced but furthemore to show a behavior and life style which measure to a social and cultural symbol for the subject.
\end{abstract}

Keywords: Eating Out, Food Culture, Urban Java, Restaurant, Culture History

\begin{abstract}
Abstrak
Perilaku makan di luar rumah merupakan salah satu kajian yang menarik terutama dalam mengkaji mengenai perilaku dan gaya hidup dalam masyarakat. Kajian merupakan pengembangan dari tesis penulis yang sebelumnya membahas mengenai budaya makan $d$ perkotaan Jawa pada periode kolonial. Pengembangan ini dilakukan dengan memasukan konsep Alan Warde dan Lydia Marteens yang mengkaji mengenai budaya makan luar rumah di Inggris. Mereka menyimpulkan bahwa perilaku makan di luar rumah berkaitan dengan perilaku kesenangan dan hiburan. Maka berdasarkan konsep tersebut pada tulisan ini dibahas hal mengenai bagaiamana pengaruh perkembangan budaya makan di luar rumah dalam keterkaitan dengan perilaku gaya hidup masyarakat perkotaan Jawa, terutama bagi kalangan elit dan menengah. Kajian ini menggunakan metodologi ilmu sejarah dengan menggunakan sumber-sumber dari media massa, iklan, dan jurnal perjalanan yang berasal dari periode tersebut. Hasil dari kajian ini bahwa perilaku dan budaya makan di luar rumah tidak saja terkait dengan pemenuhan kebutuhan, namun juga menampilkan perilaku dan gaya hidup yang memberi simbol dari status sosial dan budaya dari pelakunya.
\end{abstract}

Kata kunci: Makan di Luar Rumah, Perkotaan Jawa, Restoran, Sejarah Kebudayaan

\footnotetext{
${ }^{1}$ Kajian ini merupakan pengembangan dari salah satu bagian dalam thesis penulis Ariwibowo, Gregorius Andika, 2011, "Pendidikan Selera: Perkembangan Budaya Makan Di Perkotaan Jawa Pada Masa Akhir Kolonial", Thesis, Yogyakarta: Universitas Gadjah Mada.
} 


\section{PENDAHULUAN}

Pada masa kini menikmati sajian makan di luar rumah merupakan hal yang umum dilakukan oleh masyarakat yang tinggal di lingkungan perkotaan. Masyarakat urban yang biasa disibukan oleh berbagai aktivitas pekerjaan dan rutinitas kota menjadikan hidangan dan sajian luar rumah menjadi pemenuhan kebutuhan pangan sehari-hari. Berbagai warung makan dan restoran menawarkan berbagai menu dari sajian masakan rumah hingga sajian Haute Cuisine dengan harga yang sangat mahal.

Di masa lalu Indonesia banyak ditemui berbagai foto, video, dan berbagai dokumentasi media lain yang menampilkan mengenai budaya makan di luar rumah. Dalam beberapa foto misalnya dapat ditemui beberapa restoran, warung, dan pedagang kaki lima yang menjual berbagai jenis makanan dengan para pembelinya yang turut menggambarkan latar belakang sosial dan budaya mereka.

Kajian mengenai budaya di luar rumah merupakan kajian yang menarik, hal ini karena melalui kajian ini dapat disaksikan mengenai dinamika masyarakat urban dari berbagai latar belakang budaya dan kelas sosial. Alan Warde dan Lydia Martens dalam bukunya mengenai Eating Out menyajikan beberapa aspek yang berkaitan dengan budaya makan di luar rumah. Aspek-aspek yang dapat dibahas antara lain mengenai perilaku konsumen, gaya hidup, budaya konsumsi, diferensiasi kelas sosial, kebiasaan, serta kaitan antara kemewahan dengan kebutuhan (Alan Warde dan Lydia Martens: 2003, 9-16).

Keragaman dan dinamika sosial budaya yang terjadi pada periode akhir kolonial di perkotaan Jawa menjadi daya tarik bagi kajiankajian mengenai sejarah kebudayaan. Masyarakat Hindia Belanda ketika itu terdiri dari berbagai suku bangsa dan budaya yang berasal dari berbagai belahan dunia, seperti dari Eropa dan Asia. Kebudayaan-kebudayaan dari luar ini kemudian saling berinteraksi dan beradaptasi dengan berbagai unsur-unsur budaya lokal. Melalui berbagai persinggungan warna-warna kebudayaan ini, Hindia Belanda pada periode tersebut seperti sebuah bazaar kebudayaan dimana terdapat keunikan-keunikan dari setiap karakter budaya yang saling berinteraksi dan berkomunikasi (Ariwibowo, 2011: 1) ${ }^{1}$.

Lingkungan perkotaan Jawa ketika itu menjadi wadah dari percampuran berbagai kebudayaan ini. Kemajuan ekonomi yang terjadi sepanjang abad ke-19 dan paruh awal abad ke20 menjadikan perkotaan Jawa mengalami berbagai perkembangan terutama dalam hal sarana dan infrastruktur. Ruang-ruang publik baru dan sarana-sarana rekreasi tumbuh dan berkembang sebagai media untuk memenuhi keinginan dan gaya hidup masyarakat urban ketika itu. Beberapa kota di Jawa pada pertengahan Abad ke-19 mengembangkan berbagai hunian-hunian suburban dengan dilengkapi berbagai ruang-ruang publik seperti societiet, gedung teater, pasar modern, taman hiburan, restoran, kebun binatang, dan lainnya (Ariwibowo, 2011: 4).

Kehadiran kelas menengah yang muncul seiring dengan perkembangan ekonomi dan pendidikan menghadirkan warna baru bagi lingkungan perkotaan Jawa. Akses untuk mendapatkan informasi dan ketersediaan sumber daya ekonomi yang baik memberikan kemudahan bagi mereka untuk menerapkan dan memenuhi gaya hidup terbaru. Beberapa foto menunjukan bagaimana kalangan kelas menengah ini menghabiskan malam mereka di Soos atau makan bersama para kerabatnya di sebuah restoran dengan diselingi oleh pestapesta dansa. Adapun yang menarik yakni apabila pada masa kini bagi kalangan kelas menengah menghabiskan waktu di luar rumah dengan menikmati berbagai hiburan dan makanan di sebuah restoran adalah hal yang biasa, terutama untuk menikmati sajian di sebuah restoran cepat saji, namun di masa lalu menikmati sajian di sebuah restoran memiliki citra yang mewah dan bergengsi. Tidak heran apabila dalam sebuah foto dapat ditemui tamu yang mengenakan setelan jas atau gaun.

Pembukaan Terusan Suez dan penemuan kapal uap pada pertengahan Abad ke-19 telah membuat transportasi antara Eropa, Amerika, dan Hindia menjadi lebih mudah. Selain bertambahnya komunitas kelas menengah Eropa yang melakukan mobilitas ke Hindia, rupanya terdapat rombongan pelancong, turis, dan kelompok orientalis yang menggunakan kemudahan ini untuk melakukan perjalanan dan ekplorasi wisata di Hindia. Hadirnya pariwisata di Hindia berdampak pada berkembangnya berbagai inovasi pelayanan terhadap para turis ini. Para pelaku industri pariwisata di Hindia mengembangkan berbagai inovasi pelayanan untuk memberikan kenyamanan dan kesan yang 
baik tentang Hindia Belanda kepada para turis. Maka tidak heran apabila pada periode itu banyak dibangun berbagai hotel, restoran, dan sarana pariwisata, selain itu juga dikembangkan berbagai menu dan penyajian makanan yang unik dan menarik yang memberikan kesan akan kekhasan budaya makan di Hindia Belanda.

Kajian ini melihat perkembangan budaya makan luar rumah di perkotaan Jawa pada masa periode akhir kolonial. Kemajemukan budaya, pertumbuhan ekonomi, gaya hidup masyarakat kelas menengah, dan perkembangan turisme telah menciptakan perubahan dalam bentuk-bentuk budaya makan di Hindia Belanda ketika itu. Kajian ini ingin melihat mengenai bagaimana bentuk-bentuk budaya makan dan sajian makanan luar rumah yang berkembang dan dihadirkan di perkotaan Jawa?

Modernisme, pertumbuhan ekonomi, perkembangan pendidikan, dan berkembangnya kelas menengah telah menghadirkan wajah baru dalam kehidupan masyarakat urban di Jawa. Kota-kota besar di Jawa pada masa itu seperti, Bandung, Jakarta, Semarang, Yogyakarta, Surakarta, dan Surabaya banyak membangun berbagai ruang-ruang publik dan privat untuk memenuhi kebutuhan-kebutuhan kota modern. Di samping itu kemajemukan budaya yang tercipta di wilayah perkotaan ini menjadi warna yang menarik bagi kehidupan urban ketika itu. Perkotaan di Jawa menjadi simbol dan wajah modernisme di Hindia Belanda. Berbagai kondisi inilah yang melatarbelakangi pemilihan perkotaan di Jawa ketika itu menjadi latar wilayah dalam kajian ini.

Periode akhir kolonial yang berkembang dari sekitar tahun 1808 hingga 1942 merupakan periode yang menarik dalam kajian sejarah Indonesia. Periode ini merupakan puncak dari peradaban kolonialisme di Hindia Belanda. Kebijakan-kebijakan pemerintah kolonial telah menciptakan dinamika dalam perkembangan kebudayaan di Hindia Belanda. Keterbukaan dalam bidang ekonomi dan politik turut memberikan pengaruh dalam masuknya berbagai unsur baru dalam bidang kebudayaan, terutama yang terkait dengan perkembangan gaya hidup. Kajian memberikan penekanan khusus pada perkembangan gaya hidup terutama yang terkait dengan kelas menengah perkotaan dan perkembangan budaya mewah di lingkungan perkotaan.
Alan Warde dan Lydia Martens menyebut perilaku makan di luar rumah secara umum berkaitan dengan adanya hasrat atau keinginan untuk mencari pengalaman lain menikmati sajian makan yang berbeda dari kebiasaan sehari-hari di rumah. Berbagai alasan seperti, mencari menu atau sajian makan yang baru dan berbeda, bersosialisasi dengan kerabat, perayaan dan pesta, hobi menikmati sajian makan; meluangkan waktu senggang, liburan, mengisi perut karena dalam perjalanan atau terburu-buru, tidak memasak di rumah, dan berbagai alasan lainnya menjadi latar belakang bagi seseorang untuk mencari makan di luar. Warde dan Martens kemudian membagi berbagai alasanalasan ini menjadi tiga aspek utama yakni sebagai bagian dari kesenangan (pleasure), hiburan (leisure), dan kebutuhan (necessity) (Alan Warde dan Lydia Martens: 2003, 47).

Dalam kajian ini penulis ingin lebih memberikan penekanan pada aspek kesenangan dan hiburan. Kedua aspek ini sangat menarik untuk dijadikan subjek dalam pembahasan kajian ini sebab terkait dengan beberapa hal antara lain dengan kelas menengahda kelompok elit perkotan, gaya hidup, serta citra dan simbolisasi budaya, terutama budaya mewah. Menurut Marijke van der Venn, makanan dapat menunjukan status dan kelas seseorang, sebab makanan dapat dibentuk dan dikreasikan secara lebih eksklusif dari sekedar kebutuhan primer. Hasrat seseorang akan status dan nilai dalam gaya hidup yang mereka terapkan, kemudian membentuk adanya suatu perubahan dari hal yang primer menjadi yang tersier (Van de Venn, 2003: 404). Braudel secara lebih jauh menyatakan bahwa budaya mewah (luxury) dalam makanan adalah sesuatu yang jauh lebih kompleks. Ia menyatakan bahwa budaya mewah adalah suatu budaya yang bukan saja menunjukan adanya sesuatu yang khusus dan dimiliki oleh orang tertentu serta lebih menunjukan kelas dan status seseorang. Namun, budaya mewah adalah sesuatu yang dibentuk oleh golongan kaya agar mereka mampu merepresentasikan kesuksesan sosial, daya tarik, dan mimpi yang suatu hari menjadi kenyataan bagi orang miskin, serta menunjukan hal yang glamour dan menawan (Braudel, 1985: 184).

Pembentukan citra dan simbolisasi budaya mewah dalam makanan dan penyajiannya dilakukan melalui penciptaan ruang-ruang dan acara-acara yang 
merepresentasikan citra kelas sosial tertentu, seperti dalam acara gala dinner atau sajian rijstaffel dalam hotel dan restoran mewah. Jenis makanan yang dapat dikatakan memiliki simbolisasi mewah memiliki ciri-ciri sebagai berikut: 1) memiliki kekayaan cita rasa yang berasal dari berbagai rempah-rempah seperti pala, cengkeh, gula, garam, lada, cabai dan lainnya; 2) memiliki kandungan lemak yang cukup tinggi, seperti sajian olahan dari daging, sajian olahan susu, coklat, dan lainnya; serta, 3) memiliki tekstur dan bahan yang merepresentasikan citra simbolis dalam masyarakat, seperti lebih mongkonsumsi roti dibandingkan nasi, mengkonsumsi air mineral dalam kemasan dibandingkan air minum yang dimasak, dan lainnya (Van de Venn, 2003: 413414).

Karya Alan Warde dan Martens mengenai Eating Out: Social Differentiation, Consumption, and Pleasure merupakan kajian yang menarik dalam membuka ruang diskusi mengenai budaya makan di luar rumah. Kajian ini merupakan kajian sosiologi dan budaya mengenai perilaku makan di luar rumah orangorang di Britania Raya pada abad ke-20. Kajian ini memberikan gambaran yang menarik mengenai perilaku dan alasan bagi seseorang atau kelompok orang untuk memutuskan alasan mengapa mereka makan di luar rumah. Buku ini juga memberikan gambaran dari elemen-elemen apa saja yang dapat digunakan untuk menjadi media dalam pembahasan ilmiah mengenai budaya makan di luar rumah. Disamping itu buku ini juga memuat gambaran dari munculnya restoran dan budaya makan yang menggunakan elemen-elemen kemewahan pada Abad ke-19 (Warde dan Martens, 2003).

Kajian ini sendiri merupakan pengembangan dari salah satu bagian thesis Andika Ariwibowo yang mengenai budaya makan di Perkotaan Jawa pada periode kolonial. Karya Ariwibowo membahas mengenai proses adaptasi rasa dari sajian-sajian yang berkembang di Hindia ketika itu yang membentuk citarasa masyarakat urban di Jawa (Ariwibowo, 2011). Ariwibowo menyebutkan bahwa telah terjadi proses pendidikan selera dalam sajian dan budaya makan di wilayah urban Hindia ketika itu. Pendidikan selera ini merupakan pengenalan sajian dan budaya makan di perkotaan Jawa yang dipengaruhi oleh perkembangan gaya hidup dan masuknya unsur-unsur sajian makanan baru akibat terjadinya transformasi budaya karena semakin mudahnya transportasi dan komunikasi dari dan ke Hindia dari wilayah-wilayah lain. Berdasarkan kajian yang dilakukan oleh Ariwibowo tersebut, maka tulisan ini mencoba memberikan penekanan pada bentuk aktivitas gaya hidup masyarakat urban dan makna simbolik yang terkait dengan budaya makan luar rumah seperti di warung, hotel, dan restoran.

Dua kajian terakhir mengenai sejarah makanan di Indonesia disampaikan oleh Fadly Rahman (2011, 2013) mengenai sajian Rijstaffel dan sejarah perkembangan budaya, penyajian, dan asal usul jenis makanan di Indonesia. Kedua kajian Rahman ini merupakan kajian mendalam mengenai sejarah makanan di Indonesia. Dalam kajiannya mengenai Rijstaffel, Fadly melakukan kajian mendalam mengenai sejarah sajian Rijstaffel baik dari penyajian dan asal-usulnya. Namun bebrbeda dengan kajian Fadly pembahasan mengenai Rijstaffel di dalam tulisan ini ingin menekankan pada aspek gaya hidup dan kesan dari orang-orang yang pernah menikmati Rijstaffel di masanya. Sementara dalam thesisnya Fadly pun secara apik dan mendalam mengupas mengenai asal-usul sajian makanan yang dikonsumsi oleh penduduk Indonesia dari masa kolonial hingga kemerdekaan. Ia banyak menggunakan berbagai sumber terutma dari resep makanan, laporan kajian, arsip kolonial dan berbagai sumber terkait yang mengupas mengenai kekayaan kuliner di Indonesia. Namun sedikit berbeda dengan Fadly tulisan ini hanya lebih memfokuskan pada aspek gaya hidup terutama budaya makan di luar rumah. Kajian ini mencoba melihat pada berbagai sajian makanan dan keunikan gaya hidup yang muncul dan berkembang terutama di sekitar warung dan restoran yang merupakan salah satu pusat aktivitas gaya hidup masayarakat, terutama pada era kolonial.

\section{METODE}

Kajian ini merupakan kajian sejarah maka akan menggunakan metodologi sejarah yang antara lain berupa pemilihan tema, pengumpulan sumber, kritik sumber, dan proses penulisan. Sumber-sumber yang digunakan dalam kajian ini antara lain akan menggunakan sumber berupa fotografi, berita perjalanan, dan media massa yang membahas tema terkait. Alasan ini diambil, sebab ketiga sumber ini dapat merepresentasikan kehidupan sehari-hari 
dan rutinitas masyarakat pada masa akhir kolonial. Ketiga sumber ini merekam mengenai realita dan ornamen-ornamen kehidupan dalam masyarakat, terutama untuk menemukan makna simbolis dari pengaruh peradaban material dalam masyarakat (Ariwibowo, 2011: 27).

Fotografi kolonial Belanda dijadikan bahan analisis dalam kerangka "tekstual", dikarenakan sifatnya yang begitu berakar dalam nostalgia kebudayaan "Indis" yang secara aktif direproduksi. Foto-foto mengenai era keemasan kolonial tempo doeloe menawarkan suatu proses tanpa mediasi untuk memasuki dimensi-dimensi kultural masa lampau. Jean Gelman Taylor memandang foto-foto sebagai media yang digunakan oleh elit kolonial untuk mewakili dunia mereka. Ia menunjuk perbedaan antara wilayah privat dan wilayah publik yang menyertai bangkitnya negara kolonial. Bagaimanapun foto-foto tersebut tidak hanya terbatas pada suatu wilayah privat, namun juga menunjukan suatu propaganda kebudayaan Eropa (kesenangan dan kemewahan dalam pandangan Eropa) terhadap citra publik di masyarakat Hindia serta mengenai ekspresi kepercayaan diri kelas kulit putih pada koloni tersebut (Nordholt, 2005: 9-10 ).

Kajian ini juga menggunakan sumbersumber berupa jurnal-jurnal perjalanan yang dibuat oleh beberapa pelancong, orientalis, biro perjalanan, dan wisatawan yang mengunjungi Hindia Belanda pada rentang periode pertengahan Abad ke-19 hingga paruh awal Abad ke-20 (Elizah R. Scidmore, 1897; Augusta de Wit, 1905; H.W. Ponder (tt); dan Guide and Tourist Handbook, $\mathrm{tt}$ ). Dalam jurnal-jurnal perjalanan ini terekam berbagai kondisi lingkungan perkotaan dan pedesaan, gaya hidup, kehidupan rumah tangga, hubungan kekerabatan, interaksi sosial, hubungan antar etnis, dan hal lain yang terkait tentang keseharian dalam masyarakat perkotaan di Jawa. (Ariwibowo: 2011, 30).

Penggunaan sumber-sumber berupa fotografi dan jurnal perjalanan mampu

\footnotetext{
2 Boulangier pada awalnya menyajikan menu makan berupa sup seperti bouillon dan pot-au-feu. Menu ini sangat digemari ketika itu karena sup disajikan dengan berbagai rempah dan tanaman herbal yang memiliki harga yang sangat mahal ketika itu. Menu ini sangat digemari oleh kalangan borjuis Prancis kerena disajikan hangat, memiliki rasa yang enak, dan memberikan manfaat kesehatan terutama pada saluran pencernaan. Maka tidak heran bila restoran memiliki arti "penyembuh kembali" karena menu
}

memberikan warna tersendiri dalam kajian sejarah kebudayaan. Kedua sumber ini memberikan sudut pandang lain dalam kajian sejarah Indonesia. Karena kedua sumber ini merekam ornamen-ornamen gaya hidup dalam kebudayaan seperti pakaian, mode rambut, makanan, dan aktivitas yang ada di masyarakat yang selama ini jarang terekam dalam sumbersumber formal yang berasal dari arsip. Sudut pandang dalam fotografi dan jurnal-jurnal perjalanan inilah yang pada akhirnya menjadi fragmen-fragmen baru yang dapat menyempurnakan rekonstruksi sejarah nasional yang tidak melulu terbatas pada pebahasan dalam bidang politik, ekonomi, dan sosial. Melalui sumber-sumber ini juga akan melihat sejarah yang tidak hanya terbatas pada konflik antara penjajah dan terjajah, namun juga dapat dilihat sebagai bagian dari interaksi sosial dan kultural dari dua elemen yang saling bertentangan ini pada era kolonial.

\section{HASIL DAN PEMBAHASAN Perkembangan Restoran di Eropa Hingga Abad Ke-19}

Pada tahun 1765 seorang pemilik kedai anggur (wine) bernama A. Boulangier menyajikan menu Kaki Domba dengan Saus Putih yang biasa disajikan di Istana Versailles dan berbagai menu menarik lainnya di kedai anggur miliknya. Penyajian anggur dan jenis makanan yang tergolong mewah pada masanya ini kemudian disebut sebagai awal munculnya restoran modern pertama di Eropa. Para pengunjung restoran ini adalah para tamu yang berasal dari kelas borjuis Prancis. Restoran memiliki arti yang sama dengan restoring atau dalam bahasa Indonesia berarti menyehatkan kembali. ${ }^{2}$ Boulangier memiliki semboyan Venite ad me, vos qui stomacho laboratis et ego restaurabo vos (Datanglah padaku wahai kamu yang lapar, aku akan menyembuhkanmu). Boulangier juga menyajikan menu a la carte (menu yang bisa dipesan terpisah,) sesuai

yang disajikan memiliki manfaat yang baik bagi kesehatan. Restoran menjadi tujuan utama bagi kalangan borjouis dan nouvelle riche karena kedua kalangan ini mulai enggan untuk mempekerjakan juru masak, karena kondisi ekonomi di Prancis saat itu. Faktor inilah yang melahirkan tren manie des diners (makan malam mania) di Prancis yang kemudian menyebar ke kota-kota besar Eropa (Braudel, 1985: 189; Snoodgras, 2013: Restaurant) $2 ; 15$. 
dengan pesanan khusus dari para tamunya (Snoodgras, 2004: 819).

Boulangier menyediakan daftar menu dan harga yang tepat untuk setiap makanan dan minuman yang ia sajikan. Ia juga menggunakan bahan makanan dan perlengkapan memasak serta makan yang bersih mengingat kebersihan pada masa itu telah menjadi perhatian, sebab Eropa baru saja bebas dari wabah "Black Death" yang mematikan (Snoodgras, 2004: 819). Pada 1783 Antoine Beauvilliers seorang juru masak Louis XVIII membuka sebuah restoran di Paris bernama "Grande Taverne de Londres". Restoran ini merupakan restoran yang sangat mewah. Beauvilliers melengkapi restorannya dengan cermin yang sangat besar, meja dan kursi yang mewah, pemanas ruangan, dan lampu kaca yang indah. Restoran ini mampu menampung hingga 300 orang. Selain menu-menu masakan yang enak dan beragam-menu makanannya juga ada yang berasal dari Inggris, Beuvilliers juga mendandani para pelayan di restorannya dengan pakaian yang baik, ia juga memberikan pelayanan dengan datang ke meja para tamunya untuk mengobrol atau menanyakan kualitas makanan yang ia sajikan (Snoodgras, 2004: 820).

Revolusi Prancis 1789 membawa dampak pada perkembangan restoran di Eropa dan dunia. Juru masak-juru masak terkenal dari Prancis banyak yang meninggalkan tanah airnya untuk mencari peruntungan di tempat lain. Salah satu juru masak ini adalah Marie-Antoine Carême. Carême berasal dari keluarga kurang mampu di Prancis ia kemudian meniti karir sebagai juru masak hingga kemudian dipercaya menjadi juru masak oleh Raja George IV dari Inggris dan Tsar Alexander dari Rusia. Carême kemudian dikenal sebagai seorang desainer masakan, ahli pembuat kue, dan seorang ahli gastromi, ia juga merupakan seorang penemu sajian Haute Cuisine atau Grand Cuisine yakni sajian khusus dan mewah yang biasa dipesan oleh kalangan elit (Snoodgras, 2004: 820).

Haute Cuisine yang disajikan oleh Carême terinspirasi oleh seorang arsitek abad ke-16 asal Italia bernama Andrea Paladio.

\footnotetext{
3 Haute Cuisine atau sajian makan adi-luhung pertama kali dikembangkan oleh Marie-Antoine Carême pada abad ke-19, lalu kemudian oleh Escofier sajian ini dijadikan sajian utama di restoran-restoran dan hotel-hotel besar, serta dalam acara-acara besar. Haute Cuisine merupakan sajian makan yang disajikan khusus untuk para kalangan elit memperhatikan kualitas menu
}

Paladio merupakan seorang arsitek yang sangat memperhatikan detail dan keindahan dalam setiap rancangannya. Carême kemudian membuat makanan yang lebih memperhatikan desain keindahan visual, baru kemudian memperhatikan kualitas bahan dan rasa. Konsep ini kemudian menjadi rujukan utama dari sajiansajian makan malam di seluruh dunia termasuk di Hindia Belanda hingga awal abad ke-20 (Keetle dan Ornelas (ed.) vol.2, 1999: 1214).

Pada periode menjelang pergantian abad menuju abad ke-20 kembali terjadi kembali perkembangan dalam industri restoran. GeorgesAuguste Escoffier menjadi tokoh sentral dari perubahan ini, ia juga dikenal sebagai "Bapak Sajian Makan Modern Prancis". Ia melakukan revolusi dalam hal penataan dapur, pembagian tugas para staf restoran, membuat berbagai menu baru dengan berbagai bahan dari seluruh dunia, dan mengembangkan berbagai sajian masakan mewah (Haute Cuisine) yang diperuntukan bagi kalangan elit. ${ }^{3}$ Escofier memiliki semboyan "Faites Simple!" ("buat ini sederhana!"), melalui semboyan ini ia ingin agar para tamu yang makan di restorannya merasa nyaman dan senang (Snoodgras, 2004: 354-356; Snoodgras, 2013: Escoffier, Georges Auguste).

Menjelang pergantian abad berkembang jenis sajian makanan baru yang dikenal sebagai Nouvelle Cuisine. Sajian ini merupakan sajian yang mengedepankan rasa-namun tetap memperhatikan tampilan dari makanan, terutama berbagai menu-menu eksotik yang berasal dari luar Eropa. Di Hindia Belanda sajian ini berkembang menjadi bentuk sajian Rijstaffel, yakni sajian makanan dan budaya akan yang muncul sebagai akulturasi antar budaya yang ada di Hindia Belanda (Keetle dan Ornelas (ed.) vol.2, 1999: 1214; Ariwibowo, 2011: 165-174).

\section{Perkembangan Kota dan Masyarakat Urban di Jawa}

Memasuki abad ke-19 terjadi perubahan politik yang cukup penting di Hindia Belanda. Jatuhnya VOC dan kehadiran pemerintahan Prancis dan Inggris membawa perubahan dalam bidang kebudayaan. Masa pemerintahan

dan penyajian yang baik. Haute Cuisine menggunakan berbgai bahan-bahan makanan eksotois dari seluruh dunia untuk menghasilkan kualitas rasa dan masakan yang baik. Haute Cuisine biasa disajikan dalam pesta-pesta mewah dan di restoranrestoran besar yang kemudian dilanjutkan dengan pesta dansa (Snoodgras, 2013: Haute Cuisine) $)^{14}$. 
Daendles dan Raffles telah membawa ide-ide dan unsur-unsur budaya Eropa ke Hindia, terutama di wilayah perkotaan. Herman W. Daendles memiliki peran dalam membawa modernism ke lingkungan perkotaan di Jawa. Di sampimg pembangunan Jalan Raya Pos, Daendles juga memerintahkan suatu pengembangan hunian baru di Batavia, yakni kawasan suburban, Weltevreden, yang memiliki arti "sangat memuaskan" (Nas, 2007: 318; Hannigan, 2015: 87).

Weltevreden merupakan suatu hunian bagi para penduduk Eropa di Batavia. Di kawasan ini terdapat berbagai restoran, hotel, teater, dan klab yang merupakan tempat hiburan bagi para penduduk Eropa dan elit pribumi. Pengembangan kawasan Weltevreden ini kemudian juga diikuti kawasan-kawasan suburban di berbagai kota lain di Jawa. Bila Daendles melakukan perubahan fisik kota, maka Raffles melalui istri pertamanya Olivia Raffles melakukan perubahan dalam gaya hidup serta perilaku elit dan perempuan Eropa di Hindia Belanda (Van De Wall, tt; Hannigan, 2015: 124127).

Olivia Mariame Raffles merupakan sosok penting dibalik perubahan gaya hidup elit dan perempuan Eropa di Batavia. Sebelum kedatangan Olivia Raffles ke Batavia, perempuan-perempuan Indo dan Eropa di Batavia terbiasa mengenakan sarung, kebaya, dan mengunyah sirih persis seperti perempuanperempuan bumiputera, bahkan Gubernur Jenderal Inggris menyebut perempuanperempuan ini "Mengerikan!". Olivia merupakan seorang perempuan aristokrat, ia gemar mengumpulkan benda-benda seni dan memberi perhatian pada penampilan dan kecantikan perempuan. Ia begitu terkejut dengan perempuan-perempuan di Batavia ketika itu yang tidak mencerminkan gaya elegan khas peremuan-perempuan terhormat Eropa (Van De Wall, tt: 4-5; Hannigan, 2015: 125).

Olivia pernah memerintahkan kepada perempuan-perempuan ini agar memperhatikan penampilan mereka bila datang ke pesta-pesta yang ia adakan, serta diharapkan agar tidak mengunyah sirih dan membawa jongos atau babu ke pesta. Olivia juga berpesan agar para perempuan ini memperhatikan bentuk tubuh mereka dan penampilan mereka. Pandangan Olivia yang kontroversial ini ini merupakan suatu bentuk resistensi budaya dan pengukuhan simbol-simbol "keadaban" bagi perempuan Eropa, yang menurutnya telah berperilaku tidak jauh berbeda dengan kaum bumiputera (Van De Wall, tt: 5; Hannigan, 2015: 126-127).

Pada tahun 1816 didirikanlah "Instituut voor Jonge-Jufvrouwen" oleh Mevrouw Gronovius di Moenswijk yang merupakan bekas kediaman Adriaan Moens, seorang mantan direktur dari VOC. Pendirian sekolah ini dilatar belakangi oleh alasan yang sama seperti yang dikemukakan oleh Olivia Raffles mengenai wanita di Hindia pada saat itu. Gronovius melihat bahwa wanita di Hindia pada saat itu tidak menunjukan sikap yang terpandang dan terhormat. Salah satu persoalan yang mendasar yang ia lihat adalah bawa wanita di Hindia kurang memiliki kesopanan dalam berbicara, bahkan dalam bahasa Belanda sendiri, demikian pula dengan sikap (manners) dan etika (etiquette) ketika dalam resepsi-resepsi kenegaraan (Hotel Des Indies, 1949: th).

Melihat apa yang dilakukan oleh Olivia Raffles dan Mevrouw Gronovius ini sungguh menarik. Bahwa dikalangan elit Eropa di Batavia pun mereka mengalami proses westernisasi dan modernisasi dalam hal gaya hidup. Kondisi Hindia yang jauh dari Eropa dan jarak perjalanan yang harus ditempuh berbulan-bulan membuat tren yang berkembang di Eropa seakan tidak menyentuh Hindia. Dominasi budaya patriarkal juga mempengaruhi sulit berkembangnya budaya barat di kalangan elit Eropa ini. Orangorang Eropa yang hidup di Hindia biasanya adalah para pegawai pemerintah dan pedagangpedagang yang tidak memperhatkan gaya hidup. Mereka juga terbiasa mengambil para perempuan bumiputera sebagai pendamping, sehingga hal ini berdampak pada lambatnya perkembangan gaya hidup Eropa di Hindia.

Pembukaan Terusan Suez dan semakin mudahnya akses media dan informasi memberikan jalan bagi perkembangan gaya hidup modern di Hindia. Perubahan tata ruang kota yang semakin baik pada pertengahan Abad ke-19 di Jawa memberikan ruang bagi berkembangnya ruang-ruang publik dan privat yang menyediakan sarana hiburan, termasuk di dalamnya restoran dan hotel.

\section{Dari Warung Hingga Restoran: Budaya Makan Luar Rumah di Perkotaan Jawa}

Sebelum munculnya restoran-restoran dan hotel-hotel yang menyajikan dan menjual 
berbagai jenis makanan jadi, masyarakat Jawa telah mengenal kehadiran warung dan para pedagang makanan yang berada di pasar, pusatpusat aktitifitas masyarakat, dan pinggir-pinggir jalan. Augusta de Wit dalam perjalanannya ke Jawa juga melukiskan kehadiran warungwarung ini. Setelah mandi pagi, sebelum berangkat beraktifitas orang-orang bumiputera akan menghabiskan waktunya untuk sarapan di warung-warung makan yang terdapat di sekitar daerah terbuka dan ramai di sekitar tempat tinggal mereka. Penjual makanan di Jawa terdapat dalam beberapa jenis yang pertama adalah penjual makanan yang membawa dagangannya dalam keranjang dengan pikulan; kedua adalah penjual makanan yang membawa dagangan makanannya dengan cara digendong; serta ketiga adalah penjual yang membuka warungnya di tempat-tempat keramaian dan berdiam di salah satu ruang di tempat tersebut, namun tidak permanen (De Wit, 1905: 117). mengatakan bahwa suasana di warung ini begitu riuh dan ramai, para pengunjung saling berbincang dan tertawa secara bebas membicarakan nasib kehidupan mereka dan cerita-cerita yang terjadi di Batavia selama beberapa waktu, seperti bisnis, cinta, nasib, dan segalanya (De Wit, 1905: 117-118).

Warung-warung ini menurut pengamatan De Wit selama ia berada di Batavia terdapat di sekitar wilayah Tanah Abang, Koningsplein (Sekitar Lapangan Banteng sekarang), Meester Cornelis (Jatinegara Sekarang), serta tersebar di pusat-pusat keramaian penduduk bumiputera seperti di pasar, sekitar stasiun kereta api, pinggir sungai dan kanal, serta di sekitar perumahan. Para pedagang ini menjajakan dagangannya dengan cara berkeliling sambil membunyikan piring, gelas, atau berteriak untuk menandakan kehadirannya (De Wit, 1905: 118). Para pedagang ini menjual berbagai jenis makanan mulai dari nasi dengan lauk ikan asin

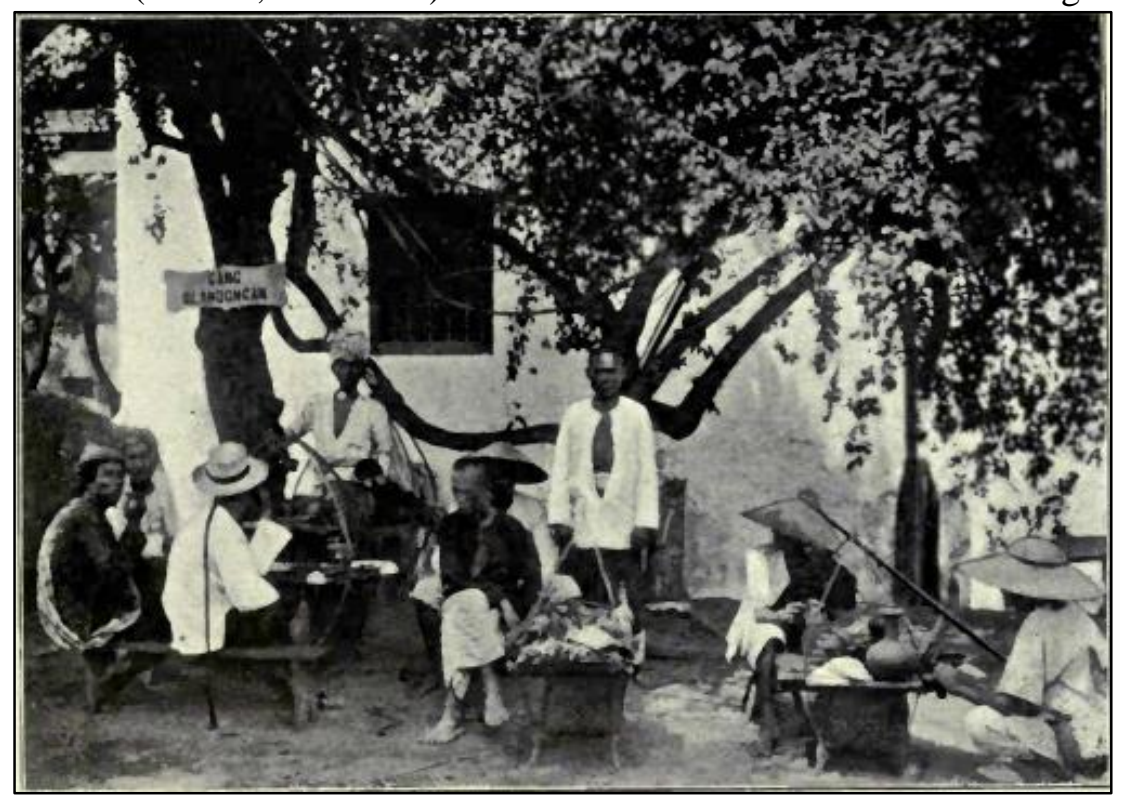

Gambar 1. Para Pedagang makanan dan pembelinya di Batavia sekitar awal abad ke-20

(Sumber: De Wit, 1905: 115)

Para pengunjung di warung-warung makan ini sangat banyak dan mereka biasanya duduk lesehan dengan menyilangkan kaki mereka. Di warung-warung ini dapat disaksikan kehidupan sosial masyarakat bumiputera kelas bawah dengan segala cerita kehidupan mereka. Para pengunjung warung-warung makan ini terdiri dari penarik sado dan gerobak, pedagang kecil, tukang siram air, pegawai di gubernemen, polisi bumiputera, pelayan dan pembantu, orangorang Tionghoa bahkan haji dan ulama. De Wit dan sambal, aneka jenis kue-kue, bola ketan yang disajikan dengan kelapa parut, dan aneka jenis makanan lain (De Wit, 1905: 118-119).

Berkembangnya kawasan hunian suburban di perkotaan turut menghadirkan berbagai fasilitas pendukungnya. Restoran, hotel, klab, sarana olahraga, bioskop, dan berbagai sarana hiburan lain hadir untuk melengkapi kawasan hunia suburban yang biasa dihuni oleh kalangan elit dan menengah perkotaan. Di Bandung, Jalan Braga menjadi 
pusat dari ajang pamer dan gaya hidup masyarakat pada masa itu. Di sepanjang jalan ini terdapat berbagai sarana hiburan antara lain Societiet Concordia (tempat perkumpulan para elit Eropa atau kalangan elit lain yang mendapat status Eropa), Societiet Ons Genoegen (Tempat berkumpul kalangan menegah Belanda dan masyarakat Indo-Belanda), Societiet Mardi Hardjo (Tempat berkumpulnya kelas menengah bumiputera), Hotel Savoy Homann, Restoran Maison Bogerijen, Restoran Ice Cream Baltic dan beberapa tempat hiburan lain.

Di perkotaan Jawa pada periode antara pertengahan abad ke-19 hingga awal abad ke-20, restoran dan rumah makan mengalami perkembangan. Restoran-restoran ini dikelola oleh orang-orang Eropa, Tionghoa, hingga orang-orang pribumi. Disamping berfungsi sebagai penyedia makanan yang mudah dan praktis bagi para pekerja di perkotaan, restoranrestoran ini juga beralih status menjadi bagian simbol kemewahan dalam jamuan makan di perkotaan.

Dalam sebuah iklan di majalah "Hotelbald," tedapat sebuah restoran yang bernama "Café-Restaurant Capitol." Restoran ini menawarkan kenyamanan tempat dan makanan Eropa yang eksklusif. Restoran yang terletak di Batavia ini menyediakan fasilitas ruang makan yang besar dengan tempat yang sangat nyaman (Het Hotel Blad, 1937: 267). Disamping itu terdapat pula sebuah promosi sebuah restoran dalam buku panduan ke Jawa yang dikeluarkan oleh Official Tourist Beaureu. Restoran yang terletak di daerah Noordwijk ini menawarkan sajian makan malam yang nyaman dengan suasana daerah sub-urban Batavia yang nyaman dan indah, sehingga para pengunjung dapat bercengkrama sambil menikmati sajian makan di restoran ini (Guide and Tourist Handbook, tt: 22). Sementara dalam sebuah iklan di majalah wisata "Mooi Djokjakarta"

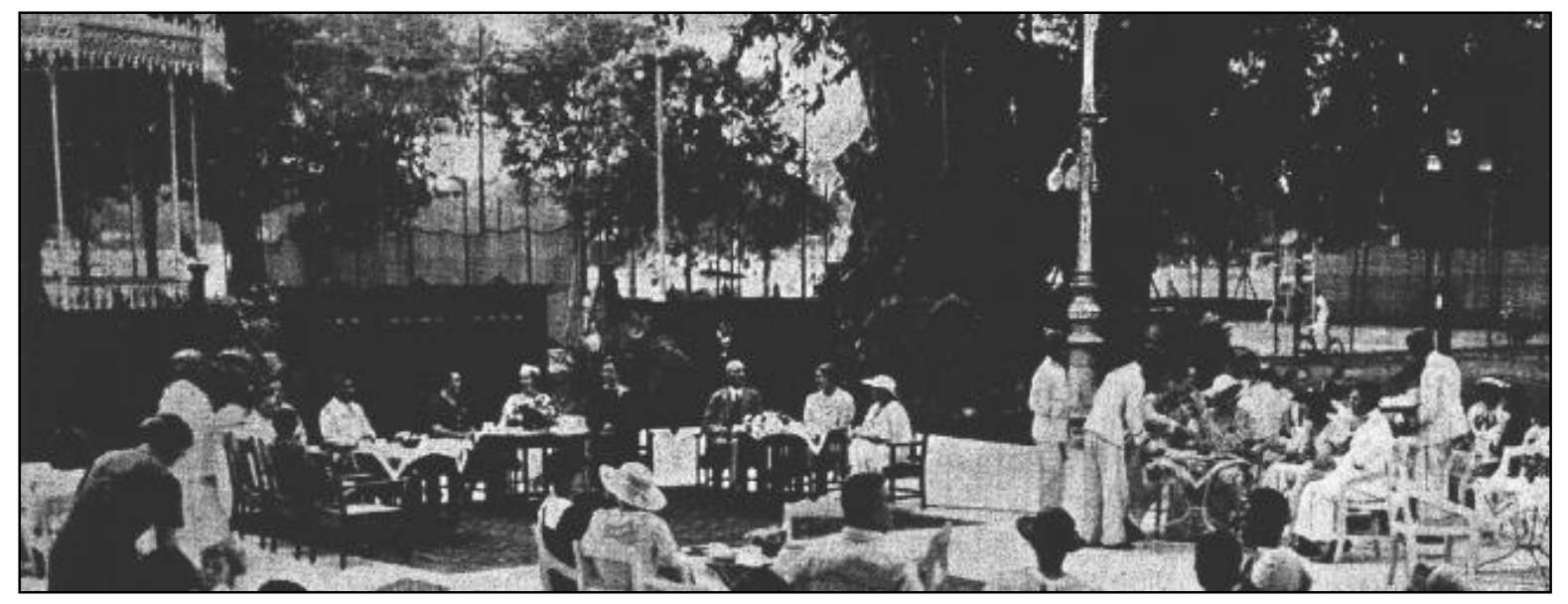

Gambar 2. Suasana pada sore hari di restoran Societiet Concordia Batavia (Sumber: Majalah Huisvrouw van Indie, 1936)

dari gaya hidup masyarakat. Perkembangan industrialisme telah memunculkan kelas pekerja yang menghadirkan budaya konsumeristis dan gaya hidup material, dimana status sosial didasarkan pada simbol-simbol baru dalam ruang perkotaan, termasuk restoran. Restoranrestoran di Jawa pun segera menyesuaikan posisi mereka dengan kalangan kelas manakah yang akan menjadi pelanggan mereka. Restoranrestoran ini segera menjadi simbol identitas dan gaya hidup baru bagi kalangan kelas menengah perkotaan untuk menikmati sajian makan di samping kehadiran hotel, yang juga menjadi terdapat sebuah restoran Tionghoa bernama "Che Nam," Restoran Tionghoa ini menawarkan berbagai sajian dari masakan Tionghoa, Eropa, hingga Pribumi. Di dalam restoran ini juga terdapat tiga buah meja bilar, sehingga restoran ini juga dapat berfungsi sebagai sebuah bar (Mooi Djokjakarta, 1935, th).

Pengaruh perkembangan restoran dan hotel di Eropa pada pertengahan abad ke-19 segera mencapai ke Jawa, seiring dengan perkembangan turisme di Jawa yang didominasi oleh turis-turis yang berasal dari negara-negara Eropa. Hotel des Indies di Batavia yang 
merupakan salah satu hotel terbaik di seluruh Hindia Belanda menjadi salah satu hotel yang menyediakan fasilitas layanan makan terbaik pada periode ini. Hotel Des Indies yang berdiri pada tahun 1897 merupakan salah satu hotel termegah yang dibangun pada masa kolonial dan terletak di jantung lingkungan masyarakat elit Batavia di daerah Molenvliet (Hotel des Indies, 1949: th).

Di Bandung Restoran Maison Borgerij merupakan salah satu restoran tebaik pada masa kolonial. Restoran ini merupakan salah satu tempat berkumpul kalangan elit bandung dan para tuan-tuan tanah pemilik perkebunan (Preangerplanters) yang berasal dari sekitar Bandung. Di Restoran ini disajikan berbagai menu yang serupa dengan menu-menu makanan yang biasa terdapat di restoran mewah di Eropa. Selain beberapa menu masakan di restoran ini juga menyajikan berbagai minuman seperti anggur, bir, dan sampanye. Para pengunjung restoran ini juga dapat menikmat kue-kue tart seperti Koningin Emma Taart atau Wilhelmina Taart untuk acara-acara khusus, karena kedua kue ini harus dipesan jauh-jauh hari.

Para tamu di hotel akan dijamu oleh berbagai jenis makanan mulai dari pagi hari hingga malam hari. Pada pagi hari para tamu akan disuguhi oleh roti, susu, daging asap, ikan asap, keju, sosis, ham, roti bakar, telur, biskuit, teh, dan kopi (Scidmore, 1897: 65; Ponder, tt: 273). Orang Belanda di Hindia Belanda, memiliki tata caranya tersendiri untuk sarapan. Pertama mereka akan menggunakan pisau dan garpu untuk mengiris roti atau daging, sebab bila menggunakan tangan terkesan kurang sopan. Orang Belanda kerap kali menyajikan "Boterham" yakni sejenis roti isi atau sandwich yang terbuat dari roti yang dioleskan dengan mentega yang telah dilelehkan lalu diisi dengan potongan daging yang disusun dengan rapi, kemudian dimakan dengan menggunakan pisau dan garpu. Pada siang hari para tamu akan dijamu oleh makanan lokal yang disajikan dalam menu rijstaffel (Ponder, 1987: 273-274).

Pada malam hari para tamu di hotel dan restoran besar di Jawa akan disajikan menu makan malam dengan menu-menu makanan Eropa. Sajian makan malam ini terkadang juga digelar secara besar-besaran dan mewah dengan mengundang para tokoh berkebangsaan Eropa dan Bumiputera. Sajian makan malam yang digelar secara mewah ini (gala dinner), biasanya diadakan pada acara-acara perayaan tertentu seperti hari ulang tahun Ratu Belanda atau hari jadi suatu kota. Dalam sajian gala dinner ini tidak saja diadakan jamuan makan malam, namun acara makanan malam pun diiringi dengan berbagai hiburan seperti pesta dansa dan sajian orkes musik. Sebuah acara gala dinner di Hotel des Indies dalam acara pembukaan hotel ini pada tahun 1897 bahkan, ditampilkan sajian musik dari sebuah kelompok orkestra yang berasal dari Rusia (Hotel des Indies, 1949: tt).

Dalam acara lustrum sebuah perkumpulan di "Grand Hotel Sarangan" juga digelar acara gala dinner. Gala dinner ini selain dihadiri oleh para tokoh politik dan pengusaha berkebangsaan Eropa, juga dihadiri oleh para pejabat bumiputera seperti anggota dewan Kota Madiun Mr. Dr. Subroto bersama istrinya. Dalam acara ini para tamu diwajibkan menggunakan pakaian rapi dan sopan, seperti jas dan gaun malam. Makanan yang disajikan merupakan makananmakanan yang berasal dari Eropa, terutama dari Prancis. Makanan-makanan ini antara lain terdiri dari Queue de Saumon Froide a la Parisienlie (sejenis olahan ikan salem ala Paris), Filet de Sole a la Orley (sejenis olahan daging ikan pari), Aloyau de Boeuf Nivernaise (sejenis steak dari daging sirloin atau punggung sapi), Punch Romaine (sejenis minuman yang dibuat dari campuran rum dan jeruk nipis dan kayu manis), Ole au Gastronome (sejenis minyak atau saus), Champignon au Gratin (makanan dari olahan jamur yang dicampur dengan keju, tepung roti, dan dibakar di dalam oven), Glace Maltaise (sejenis minuman dingin), Sardines Fourres de Caviar (Olahan masakan dari ikan sarden yang dicampur dengan kaviar), Fruits assortis (aneka jenis buah yang disajikan), Moka (minuman campuran coklat dan kopi), serta berbagai jenis makanan lain yang termasuk jenis makanan Eropa yang disajikan dari bahan dan olahan khusus (a la carte) (Het Hotel Blad, 1937: 8288).

Menu-menu yang disajikan dalam sajian gala dinner merupakan menu-menu mewah yang merupakan pengaruh dari perkembangan restoran dan hotel di Eropa pada masa yang hampir bersamaan. Dalam mendukung terciptanya sumber daya manusia yang memiliki kemampuan untuk memasak berbagai jenis masakan-masakan mewah ini maka terdapat sekolah ketrampilan memasak di negeri Belanda. Sebuah iklan tentang sekolah 
perhotelan di Belanda sempat dimuat dalam salah satu edisi majalah "Hotelbald". Iklan ini berisi mengenai sebuah perhotelan yang mengajarkan mengenai manajemen dan pengelolaan hotel, pelayanan di dalam hotel, ilmu gastronomi, dan berbagai kegiatan lain yang menyangkut bidang perhotelan. Biaya yang dibutuhkan berkisar antara $f 75$,- hingga $f 250$,per bulan (Het Hotel Blad, 1937: 92-93).

Alan Warde dan Lydia Martens mengatakan bahwa makan di luar rumah terutama yang menyangkut pada aspek hiburan dan kesenangan selalu terkait dengan sesuatu yang spesial atau khusus. Menikmati sajian makan di luar merupakan sebuah momen spesial karena bukan saja pilihan menu makanan yang istimewa dan lain dari sajian makan yang seharihari dinikmati, namun juga terkait dengan waktu dan momen kebersamaan yang istimewa seperti pesta, perayaan, berkumpul bersama kerabat atau keluarga, makan malam dengan pasangan, atau hanya sekedar ingin mencari hiburan di tengah segala rutinitas (Warde dan Martens, 2003: 47-48). Warung dan restoran kemudian beralih fungsi dari sekedar tempat makan menjadi sebuah media dan ruang yang dapat memenuhi keinginan para pengunjungnya sebagai sarana hiburan dan sosialisasi. Tempat makan di wilayah perkotaan, terutama restoran kemudian berusaha menghadirkan suasana makan baru. Pengayaan variasi menu, peningkatan kualitas pelayanan, dan penambahan fasilitas hiburan membuat suasana makan tidak saja sebatas pada perbincangan di meja makan. Permintaan akan hal-hal yang diutarakan inilah yang menjadi latar belakang munculnya restoran-restoran mewah di Jawa pada akhir periode kolonial. Bagi kalangan kelas menengah dan elit di Perkotaan Jawa ketika itu restoran menjadi ruang hiburan dan sosialisasi, selain itu restoran dan tempat makan mewah ini juga menjadi penanda status sosial yang membedakan antara mereka dengan kelompok sosial lain yang berada di luar lingkungan sosial mereka.

\section{Rijstaffel Sebagai Menu Makan Siang Terbaik}

Masyarakat urban di Jawa pada masa pertengahan abad ke-19 hingga paruh pertama abad ke-20 sangat mengenal sajian rijstaffel. Rijstaffel merupakan sajian nasi lengkap dengan berbagai olahan masakan khas dari berbagai kelompok sosial di perkotaan Jawa, seperti masakan Jawa, Tionghoa, dan masakan olahan masyarakat Indo-Eropa. Rijstaffel merupakan sajian utama yang sangat mewah karena bukan saja menampilkan sajian makanan yang mewakili kekhasan budaya masyarakat Hindia Belanda, namun disajikan dalam ruang-ruang eksklusif di hotel dan restoran mewah di perkotaan Jawa. Kehadiran rijstaffel juga ditunjang oleh perkembangan pariwisata ke Hinda Belanda. Rijstaffel menjadi menu sajian khas bagi para turis karena merupakan sajian yang mampu mewakili identitas keanekargaman citarasa masakan di Hindia Belanda.

Pada masa sebelum dekade kedua abad ke-20 menu rijstaffel yang lengkap dan komplit disajikan hampir setiap hari. Di Hotel des Indies sajian rijstaffel lengkap (Groote Rijstaffel) hanya disajikan pada hari minggu, sedangkan di Grand Hotel Djokja, menu rijstaffel hanya disajikan pada hari selasa dan jumat. meskipun setiap siang hari juga disajikan makan siang dengan menu makanan lokal bagi para pengunjung hotel-hotel ini (Mooi Djokjakarta, 1935: th). Sajian groote rijstaffel di Hotel des Indies ini terdiri dari sekitar dua puluh hingga tiga puluh menu makanan lokal khas Hindia Belanda. Dalam buku kenang-kenangan 50 tahun Hotel des Indies disampaikan bahwa sajian groote rijstaffel ini merupakan menu rijstaffel istimewa yang disajikan yang disajikan di hotel ini (spesial de la maison). Rijstaffel menjadi sajian yang istimewa dan spesial yang disajikan di hotel-hotel di Jawa pada masa pertengahan abad ke-19 hingga akhir masa kolonial Belanda pada akhir abad ke-20. Dalam iklan di majalah "Mooi Djokjakarta" pada 1935, tiga buah hotel besar di Yogyakarta yakni "Hotel Toegoe", "Grand Hotel Djokja", dan "Hotel Mataram", memasukan rijstaffel sebagai salah satu daya tarik bagi para turis untuk singgah di hotel-hotel ini (Hotel des Indies, 1949: th).

Dalam buku panduan tentang perjalanan wisata ke Jawa banyak ditampilkan mengenai sajian-sajian kuliner di dalam hotel-hotel di Jawa. Pada masa akhir abad ke-19 hingga paruh pertama abad ke-20 menu-menu masakan lokal (rijstaffel) dari masyarakat Jawa menjadi sajian utama dan menu bergengsi dalam sajian di hotelhotel tersebut. Banyak kisah mengenai rijstaffel ini dalam memoar-memoar yang ditulis oleh para wisatawan yang berkunjung ke Jawa pada 
masa antara akhir abad ke-19 dan paruh pertama abad ke 20 mengenai rijstaffel.

Augusta de Wit, H.W. Ponder, dan Elizah Scidmore memiliki kenang-kenangan ketika mereka menyantap rijstaffel ini untuk pertama kalinya. Augusta de Wit yang begitu kagum dengan suasana Batavia dari saat ketika pertama kali menginjakan kakinya di Tanjung Priok hingga menuju ke hotel tempat ia tinggal sementara di Batavia, semakin terhenyak kaget dengan jamuan makan siang yang disajikan di hotel. Sajian makan siang di hotel tersebut disajikan tidak di dalam sebuah ruangan seperti layaknya sebuah restoran pada umumnya, namun disajikan diteras atau beranda belakang hotel tersebut. Beranda belakang hotel tersebut dirancang sebaik mungkin dengan menggabungkan arsitektur Eropa yang kokoh dengan aneka bunga dan pepohonan di sekitar taman hotel tersebut (De Wit, 1905: 18). Makan siang tersebut disajikan oleh pelayan-pelayan bumiputera yang mengenakan potongan pakaian semi-Eropa dengan mengenakan kain sarung batik dengan ikat kepala. Para pelayan tersebut menyajikan makanan dengan berjalanan teratur mengelilingi meja makan dengan membawa makanan yang hendak disajikan (De Wit, 1905: 19).

H.W. Ponder juga menceritakan mengenai prosesi penyajian rijstaffel ini. Aneka jenis maknanan bumiputera ini dibawa oleh iringiringan pelayan yang terdiri dari lebih kurang dua puluh lima orang. Masing-masing pelayan akan membawa satu atau dua jenis makanan. Makanan yang selalu disajikan pertama adalah sayur kari, kemudian dengan susunan yang membingungkan akan datang berbagai jenis makanan seperti pisang goreng, sayur terung, bola-bola kentang, kari ayam, gulai, ayam goreng, bebek goreng, enam jenis ikan kering, risoles, kroket, pastel, sosis, telur goreng, telur rebus, sambal goreng hati, panekuk yang dipotong menyilang, lobak, irisan bawang, kelapa parut, aneka sambal, acar, dan jenis-jenis makanan lain, serta terakhir dari semua prosesi makanan ini adalah krupuk (Ponder, tt: 259).

Makanan-makanan yang disajikan dalam makan siang ini adalah makanan-makanan lokal yang menurut de Wit "tidak pernah dirasakan dimanapun di belahan bumi ini”. Sajian rijstaffel memang didominasi oleh jenis masakan dari nasi dan ayam, namun masakan olahan dari ikan dan daging juga menghiasi sajian-sajian dari rijstaffel ini. Ayam, ikan, dan daging biasanya diolah dengan bumbu lokal yang kaya akan citarasa. Disamping menu-menu olahan dari ayam, ikan, dan daging ini juga dilengkapi dengan kari, aneka jenis saus, acar, manisan buah, telur asin, pisang goreng, ikan asin, sambal goreng ati, berbagai jenis sambal, telur ikan, dan berbagai jenis kue-kue khas Jawa yang yang kaya akan bumbu-bumbu dan disajikan dengan cabe rawit (De Wit, 1905: 19).

Rijstaffel selain disajikan oleh para pelayan yang mengelilingi meja makan juga disajikan dalam bentuk prasmanan. De Wit melukiskan sajian makan dalam bentuk prasmanan ini dengan sangat menarik. Menurut de Wit, ia menemukan sajian makan siang dalam sebuah meja yang besar yang dipeenuhi oleh berbagai macam jenis makanan, seperti lusinan hidangan nasi, berbagai sajian olahan dari unggas dan ikan, ratusan jenis sambal yang terletak diantara susunan buah yang berbentuk piramid besar yang terdiri dari pisang, mangga, nanas, dan berbagai jenis buah lain (De Wit, 1905: 20). Sementara Ponder melukiskan sajian makanan ini dengan mengambil filosofi matahari dan planet-planet yang mengitarinya. Sebab aneka jenis makanan prasmanan ini ditata dengan mengelilingi sebuah mangkuk sup yang besar, seperti planet yang berada disekitar matahari (Ponder, tt: 259-260).

Sementara Elizah Scidmore menuturkan bahwa ia sangat menyukai sajian rijstaffel berupa sup ayam dengan nasi putih. Disamping itu ia juga mengatakan bahwa sajian rijstaffel ini terdiri dari berbagai jenis makanan olahan bumiputera yang disajikan dalam delapan hingga sepuluh jenis sajian makanan dengan berbagai jenis lauk yang berasal dari olahan daging seperti ayam, bebek. ikan, daging, burung, dan omlet. Ia juga menyaksikan rekannya di meja makan menuangkan kuah kari dalam nasinya, lalu dimakan bersama lauknya. Berbagai makanan yang kaya rasa ini menurut Scidmore diolah bersama dengan bahan-bahan bumiputera seperti rempah-rempah, kelapa, lada, cabai, dan lainnya (Scidmore, 1897: 29).

Sajian makan siang dengan rijstaffel ini ditutup dengan sajian salad dan daging asap dengan berbagai buah-buah tropis. Setelah makan siang ini para tamu hotel biasanya akan beristirahat siang (siesta), lalu baru kembali beraktifitas dengan menikmati suasana sore hari sekitar pukul 15.30 untuk menikmati sajian teh. 
Rijstaffel merupakan makanan yang sangat digemari oleh para wisatawan asing sebab citarasa yang kaya akan berbagai rasa yang berasal dari bumbu-bumbu yang terdapat dalam berbagai sajian makanan dalam olahan masakan yang disajikan. Makan siang merupakan saat yang ditunggu-tunggu oleh para wisatawan yang datang, sebab mereka begitu menantikan sajian rijstaffel, bahkan tak jarang para turis ini mengeluh bahwa mereka "bangun terlalu pagi" sebelum rijstaffel disajikan (Scidmore, 1897: 2425).

Sajian rijstaffel memang lebih mewakili identitas masyarakat kolonial Hindia Belanda dibandingkan dengan identitas kultural masyarakat Jawa. Menurut Ponder, rijstaffel merupakan citra sajian nasional di Hindia Belanda yang dibentuk oleh orang-orang Eropa di daerah koloni ini. Rijstaffel lahir sebagai hasil adaptasi daan asosiasi citarasa masyarakat Eropa di koloni dengan sajian nasi besar dalam perayaan seremonial atau selametan bumiputera (Het Hotel Blad, 1937: 82-88).

\section{KESIMPULAN}

Perkembangan sarana transportasi dan komunikasi yang berlangsung pada abad ke-19 memberikan pengaruh dalam perkembangan budaya dan gaya hidup. Hal ini juga berpengaruh pada semakin mudahnya interaksi dan dan pertukaran antar kebudayaan. Pembukaan Terusan Suez telah memangkas jarak dan waktu tempuh dari Belanda ke Hindia Belanda. Hal ini kemudian berpengaruh pada semakin mudahnya pengaruh budaya asing terutama yang berasal dari Eropa ke Hindia Belanda.

Salah satu bentuk gaya hidup yang berkembang akibat semakin mudahnya komunikasi antar budaya ini adalah dalam hal budaya makan, terutama dalam hal budaya dan sajian makan di luar rumah. Pada periode ini, terutama di lingkungan perkotaan, makanan bukan lagi sekedar kebutuhan utama dan hanya disajikan dalam lingkungan domestik. Masyarakat urban terutama dari kalangan elit dan menengah kini mencoba menerapkan simbol-simbol budaya yang mampu menunjukan status sosial dan budaya mereka. Restoran mampu mewakili hal ini sebab di dalam restoran mereka dapat menkmati jenis-jenis makanan yang berbeda dari yang biasa disajikan di lingkungan domestik, serta tidak setiap saat dikonsumsi sehari-hari oleh masyarakat.
Restoran juga menawarkan berbagai hiburanhiburan yang berbeda dari yang biasa ditampilkan dalam lingkungan sosial sehari-hari. Restoran terutama dalam lingkungan nasyarakat menengah dan elit juga menjadi ruang-ruang pribadi yang mampu menciptakan segregasi dan simbol-simbol yang menjadi pembeda dari kelas sosial yang satu dengan yang lainnya.

\section{Ucapan Terima Kasih}

Ucapan terima kasih pertama penulis sampaikan kepada pembimbing Tesis saya Dr. Sri Margana, M.A., M.Phil. yang telah membantu dan mengarahkan penulis dalam penyusunan tesis penulis yang menjadi sumber utama dalam penulisan karya ilmiah ini. Selanjutnya saya ucapkan terima kasih kepada Prof. Dr. Erman Aminullah, M.Sc. Apth. Yang telah membantu penyusunan karya tulis ini pada Diklat Jabatan Fungsional Peneliti Pertama di Lembaga Ilmu Pengetahuan Indonesia (LIPI).

$$
* * * * *
$$

\section{DAFTAR PUSTAKA}

Ariwibowo, Gregorius Andika. (2011). Pendidikan Selera: Perkembangan Budaya Makan Di Perkotaan Jawa Pada Masa Akhir Kolonial, Tesis, Yogyakarta: Universitas Gadjah Mada.

Braudel, Fernand. (1985). Civilization and Capitalism 15th-18th Century: The Structure of Everyday Life: The Limits of Posible, London: Colin/Fontana Press.

De Wit, Augusta. (1905). Fact and Fancies. London: Chapman and Hall Ltd.

Guide and Tourist Handbook. tt. Java The Wonderland. Batavia: Official Tourist Beareau.

Hannigan. Tim. (2015). Raffles Dan Invasi Inggris ke Jawa, Jakarta: Kepustakaan Populer Gramedia (KPG).

Hotel Des Indies. (1949). 50 jaar hotel des Indies. Batavia: Hotel Des Indies.

Keetle, Kenneth F. dan Krimchild Connee Ornelas. (ed.). (1999). The Cambridge World History of Food., Cambridge: Cambridge University Press.

Nas P.J.M. (2007). Kota-Kota Indonesia: Bunga Rampai Yogyakarta: UGM Press.

Nordholt, Henk S. (2005). Outward Appereance: Trend, Identitas, kepentingan, Yogyakarta: LkiS.

Ponder, H.W. tt. Java Pageant. London: Seeley Service \& Co. 
Rahman, Fadly. (2011). Rijstaffel; Budaya Kuliner di Indonesia 1870-1942. Jakarta: Gramedia.

Rahman, Fadly. (2013). Sejarah Makanan di Indonesia Dalam Perspektif Global, Tesis, Yogyakarta: Universitas Gadjah Mada.

Snoodgrass, Mary Ellen. (2004). Encyclopedia of Kitchen History, New York: Taylor and Francis.

Snoodgrass, Mary Ellen. (2013). World food: An Encyclopedia of History, Culture, and Social Influence From Hunter-Gatherers To The Age of Globalization, New York: Sharpe Reference.

Scidmore, Elizah R. (1897). Java: The Garden of East. New York: The Century Co.

Van der Venn, Marijke. (2003). "When is Food a Luxury?" World Archeology, vol. 34.

Wall, Van de. tt. "The Influence of Olivia Marianne Raffles on European Society in Java, 18121814," Artikel, Archeological Survey Deparment Batavia.

Warde, Alan dan Lydia Martens. (2003). Eating Out: Social Differentiation, Consumption and Pleasure, New York: Cambridge University Press.

Het Hotel Blad, No.5, tahun 1937.

Mooi Djokjakarta, 1935.

Huisvrouw van Indie, 1936. 